\title{
Analisis Pembelajaran Seni melalui Finger painting pada Anak Usia Dini
}

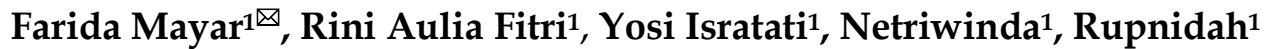 \\ Pendidikan Anak Usia Dini, Universitas Negeri Padang, Indonesia(1) \\ DOI: $10.31004 /$ obsesi.v6i4.1978
}

\begin{abstract}
Abstrak
Pembelajaran Seni yang diberikan pada tingkat Taman kanak-kanak, dimana anak dimana kita sebagai guru dituntut untuk mengembangkan seni anak dengan didukung media pembelajaran yang menarik dan menyenangkan. Penelitian ini bertujuan mengetahui bagaimana proses pembelajaran Seni kepada anak. Penelitian ini menggunakan jenis penelitian deskriptif kualitatif yaitu yaitu meneliti sebuah objek dan pencarian fakta dengan interpretasi yang tepat. Dengan teknik pengumpulan data observasi, wawancara dan dokumentasi. Analisis data yang digunakan yaitu pengumpulan data (data collection), reduksi data (data reduction), display data (data display), verifikasi dan penegasan kesimpulan (conclution drawing and verivication). Hasil penelitian menunjukkan bahwa mengenalkan konsep Seni pada anak dengan memadukan media Finger painting dapat mengembangkan seni anak usia dini di TK Harapan Kami. Dampak hasil penelitian adalah finger painting bermanfaat dalam mengembangkan kreativitas pribadi anak yang mandiri, penuh imajinasi dan mengasah bakat dalam pembelajaran Seni.
\end{abstract}

Kata Kunci: seni; finger painting; satuan paud sejenis.

\begin{abstract}
Art Learning is given at the Kindergarten level, where children where we as teachers are required to develop children's art supported by interesting and fun learning media. This study aims to determine how the process of learning art for children. This research uses descriptive qualitative research, namely researching an object and finding facts with the right interpretation. With data collection techniques observation, interviews and documentation. The data analysis used is data collection, data reduction, data display, conclusion drawing and. The results showed that introducing the concept of art to children by combining finger painting could develop early childhood art in Harapan Kami Kindergarten. The impact of the research results is that finger painting is useful in developing children's creativity that is independent, full of imagination, and sharpens talent in learning art.
\end{abstract}

Keywords: art; finger painting; similar early childhood units.

Copyright (c) 2022 Farida Mayar, et al.

$\triangle$ Corresponding author:

Email Address: mayarfarida@gmail.com (Padang, Sumatera Barat, Indonesia)

Received 20 September 2021, Accepted 13 December 2021, Published 1 February 2022 


\section{PENDAHULUAN}

Pendidikan merupakan hal terpenting dalam kehidupan manusia, melalui pendidikan manusia dapat menjadi pribadi yang berkualitas dan berkarakter. Menurut Nasution \& Yaswinda, (2020) pendidikan adalah proses pembelajaran pengetahuan, keterampilan, dan kebiasan sekumpulan manusia yang bertujuan membawa perubahan ke arah yang lebih baik. Salah satu pendidikan yang terpenting adalah Pendidikan Anak Usia Dini (PAUD). Pendidikan Anak Usia Dini adalah potensi dasar pendidikan yang diberikan kepada anakanak usia 0 sampai 8 sebagai suatu usaha untuk mengoptimalkan stimulasi sejak dini (Pebriana, 2017). Seperti yang diketahui, bahwa anak usia 0-8 tahun adalah masa golden age atau masa keemasan. Pada usia ini anak dapat menyerap segala informasi mencapai $80 \%$. Berbagai informasi yang diberikan kepada anak merupakan tugas orang dewasa di sekitarnya, baik orang tua, guru, dan yang lainnya(Umroh, 2019). Telah dinyatakan dalam Undang Undang tentang Sistem Pendidikan Nasional No. 20 Tahun 2003 Pasal 1 menguraikan tentang pendidikan yaitu:

Pendidikan merupakan usaha sadar dan terencana untuk mewujudkan suasana belajar dan proses pembelajaran agar peserta didik secara aktif mengembangkan potensi dirinya untuk memiliki kekuatan spiritual keagamaan, pengendalian diri, kepribadian, kecerdasan, akhlak mulia, serta keterampilan yang diperlukan dirinya, masyarakat, bangsa, dan negara. Beberapa aspek perkembangan yang salah satunya perlu dikembangkan adalah pendidikan seni bagi anak usia dini. Menurut Nursyam et al., (2020) Pendidikan Seni pada anak TK adalah membantu anak mengungkapkan sesuatu yang mereka ketahui dan yang mereka rasakan sehingga dapat diungkapkan diri melalui seni. Karya seni yang dimiliki oleh anak sebuah ungkapan keindahan dari sebuah peristiwa yang dirasakan. Pendidikan seni di Indonesia ada berbagai macam yaitu seni rupa, seni tari, dan seni musik, semua dikembangkan dalam dunia pendidikan sesuai tahap perkembangan dan sesuai aspek-aspek perkembangannya. Mendidik anak melalui seni, bukan hanya untuk anak yang berbakat saja, melainkan seni untuk mengembangkan potensi diri dan menumbuhkan kreatif bagi seseorang. Pendidikan seni pada anak diarahkan untuk pembentukan sikap sehingga adanya keseimbangan intelektual, dan sensibilitas, rasional dan irasional, akal pikiran dan kepekaan emosi, menjadikan manusia terampil lahir dan batin, kemampuan motorik, kognitif, psikomotor berkembang dengan baik dan optimal. Kepribadian anak lambat laun akan berkembang dan berpengaruh terhadap fungsi jiwa.

Fungsi-fungsi jiwa tersebut meliputi fantasi, sensitivitas, kreativitas, dan ekspresi. Anak melakukan kegiatan membayangkan suatu kejadian atau peristiwa yang pernah terjadi maupun yang belum dituangkan dalam bentuk karya seni disebut fantasi. Membangkitkan sebuah perasaan sedih, senang, gembira maupun marah dalam karya seni yang sudah dibuat disebut sensitif terhadap kejadian. Anak mulai menuangkan ide-ide gagasan, membuat produk, bereksperimen terhadap lingkungan sekitar menjadikan anak menjadi kreatif dan mulai mengekspresikan hasil karyanya (Fauziah, 2013). Herlina, (2013) menyatakan tentang definisi kreativitas. Kreativitas adalah kemampuan seseorang untuk menghasilkan komposisi, produk, atau gagasan apa saja yang dasarnya baru, dan sebelumnya tidak dikenal pembuatnya. Ia dapat berupa kegiatan imajinatif atau sint esis pemikiran yang hasil-hasilnya bukan hanya perangkuman. Ia mungkin membentuk pola baru dan gabungan informasi yang diperoleh dari pengalaman sebelumnya dan pencangkokan hubungan lama ke situasi baru dan mungkin mencakup korelasi baru. Ia harus mempunyai maksud atau tujuan, yang ditentukan, bukan fantasi semata, walaupun merupakan hasil yang sempurna dan lengkap. Ia mungkin dapat berbentuk produk seni, kasusasteraan, produk ilmiah atau mungkin bersifat procedural atau metodologis.

Fakhriyani, (2016) Kreativitas adalah kemampuan untuk menciptakan suatu bentuk yang baru, untuk memberikan gagasan-gagasan baru yang akan digunakan dalam pemecahan masalah atau sebagai kemampuan menghubungkan unsur-unsur yang baru dan unsur-unsur yang sudah ada pada sebelumnya. Kreativitas anak akan berkembang melalui proses 
interaktif antara lingkungan yang merangsang dan kemampuan bawaan dan saat prosesnya. Pengembangan potensi pada anak sangat efektif jika dimulai sejak usia dini sesuai tingkat perkembangan anak. Pengembangan kreativitas pada anak dimulai Pendidikan Anak Usia Dini yaitu keluarga sebagai lingkungan pendidikan pertama dan pendidikan prasekolah (Hulukati \& Hulukati, 2015). Tahap selanjutnya sesuai jenjang pendidikan dari pendidikan prasekolah sampai pendidikan perguruan tinggi, kreativitas perlu dipupuk, dikembangkan dan ditingkatkan, selain mengembangkan kecerdasan dan ciri-ciri lain yang menunjang pembangunan. 4 Berbagai kegiatan yang diberikan pada anak dapat mengembangkan kreativitas atau daya cipta untuk menjadikan anak lebih kreatif dalam menciptakan hal yang baru dan belum pernah dibuat oleh seseorang atau dapat memodifikasikan dari lama nenuju penciptaan baru. Kreativitas dalam pendidikan seni berkaitan dengan keindahan atau estetika. Kreativitas untuk anak berhubungan dengan bagaimana anak mampu menciptakan hasil karya atau bentuk baru.

Pengembangan seni anak usia dini dapat dikembangkan dengan berbagai macam media, salah satunya adalah finger painting. Menurut Anggraini et al., (2018) Finger painting adalah teknik melukis secara langsung tanpa menggunakan bantuan alat, anak dapat mengganti kuas dengan jari-jari tangannya secara langsung (Maghfuroh \& Putri, 2017). Di dalam kegiatan finger painting, anak dapat dengan bebas menuangkan imajinasi yang akan diwujudkannya. Kegiatan Finger painting pada dasarnya mudah, tidak begitu rumit, serta tidak ada aturan baku untuk melakukan kegiatan tersebut. Hal yang harus dilakukan guru adalah memberikan memotivasi serta menumbuhkan keberanian anak untuk melakukan kegiatan finger painting, yaitu untuk tidak takut tangannya kotor karena bubur warna. Menurut Ramdini \& Mayar, (2019) menyatakan bahwa Finger painting dapat mengembangkan ekspresi melalui media lukis dengan gerakan tangan, mengembangkan fantasi, imajinasi, dan kreasi, melatih otot-otot tangan/ jari, koordinasi otot dan mata, melatih kecakapan mengombinasikan warna, memupuk perasaan terhadap gerakan tangan, dan memupuk keindahan.

Finger painting adalah jenis kegiatan membuat gambar yang dilakukan dengan cara menggoreskan adonan warna (bubur warna) secara langsung dengan jari tangan secara bebas di atas bidang gambar, batasan jari di sini adalah semua jari tangan, telapak tangan, sampai pergelangan tangan (Harahap, 2019). Sedangkan menurut Pamadhi, (2008), Finger painting adalah teknik melukis secara langsung tanpa menggunakan bantuan alat, anak dapat mengganti kuas dengan jari-jari tangannya secara langsung. Pentingnya Finger painting dalam meningkatkan kreativitas dikuatkan menurut Kurniati \& Rachmawati, (2010) Finger painting dapat meningkatkan kemampuan berpikir dan berbuat kreatif serta mengembangkan kemampuan dalam mengungkapkan nilai-nilai estetika dengan menggambar karya-karya kreatif. Menurut Suwarini, (2014) Finger painting dalam perkembangan kreativitas anak adalah penting karena dapat melatih pengembangkan imajinasi, memperluas kemampuan motorik halus, dan mengasah bakat seni, khususnya seni rupa. Kemampuan berpikir kreatif harus ditanamkan sejak dini, karena kemampuan berpikir kreatif sangat penting bagi kehidupan di masa depannya.

Dengan melatih berpikir kreatif anak dapat menyelesaikan masalah secara kreatif baik dalam urusan sehari-harinya misalnya di lingkungan sekolah maupun dilingkungan keluarga. Selain itu kemampuan berpikir kreatif anak dapat mengambil tindakan secara kreatif dan tepat baik dalam keputusan sederhana ataupun yang lainnya. Pentingnya menanamkan atau melatih berpikir kreatif sejak dini bagi anak usia dini dikuatkan menurut Munandar, (2021) kreativitaslah yang memungkinkan manusia meningkatkan kualitas hidupnya. Dalam era pembangunan ini, kesejahteraan dan kejayaan masyarakat dan negara bergantung kepada sumbang kreatif, berupa ide-ide baru, penemuan-penemuan baru, dan teknologi baru. Untuk mencapai hal ini, sikap, pemikiran, dan perilaku kreatif harus dipupuk sejak dini. 
Berangkat dari beberapa hasil penelitian tersebut maka peneliti mencoba melakukan analisis terhadap pembelajaran Seni melalui media finger painting. Analisis pembelajaran Seni pada anak perlu dilakukan karena ingin mengetahui bagaimana proses pembelajaran Seni, serta mengetahui bagaimana keberhasilan penggunaan media Finger painting tersebut kepada anak di TK Harapan Kami. Oleh karena itu peneliti mengangkat judul “ Analisis Pembelajaran Seni Melalui Media Finger painting Di TK Harapan Kami Jorong ketinggian Nagari Sarilamak Kecamatan harau Kabupaten Lima Puluh Kota"

\section{METODOLOGI}

Penelitian ini dilakukan di TK Harapan Kami Jorong ketinggian Nagari Sarilamak Kecamatan harau Kabupaten Lima Puluh Kota dengan jumlah murid 15 orang dan tenaga pendiidkan 3 orang. Waktu pelaksanaanya pada semester ganjil tahun ajaran 2021/2022. Jenis penelitian ini adalah penelitian deskriptif dengan pendekatan kualitatif dikarenakan meneliti sebuah objek dan pencarian fakta dengan interpretasi yang tepat. Sejalan dengan pendapat Kristin, (2016) pentingnya penelitian kualitatif adalah untuk menjelaskan data-data yang berbentuk lisan dan tulisan, peneliti dapat memehami lebih mendalam tentang fenomena atau peristiwa-peristiwa setting sosial yang berhubungan denga fokus masalah yang diteliti. Artinya tujuan dari penelitian kualitatif yaitu untuk menemukan jawaban terhadap suatu fenomena melalui prosedur ilmiah yang dilakukan secara sistematis.

Teknik pengumpulan data dilakukan dengan observasi, wawancara, dan dokumentsi sebagai bukti bahwa peneliti melakukan pengumpulan data terhadap apa yang ingin di teliti (Creswell, 2015). Teknik analisis data menggunakan langkah-langkah yang dikemukakan oleh Sugiyono, (2015) yaitu pengumpulan data (data collection), reduksi data (data reduction), display data (data display), verifikasi dan penegasan kesimpulan (conclution drawing and verivication). Sugiyono, (2015) menyatakan bahwa aktivitas dalam analisis data kualitatif dilakukan secara interaktif dan berlangsung secara terus menerus hingga datanya jenuh. Teknik pengabsahan data dalam penelitian ini menggunakan teknik triangulasi data. Peneliti meneliti kebenaran data dari beberapa sumber seperti kepala sekolah dan guru. Teknik pengabsahan data berhubungan dengan tingkat kebenaran dari data yang telah peneliti peroleh atau kumpulkan melalui penelitian kualitatif.

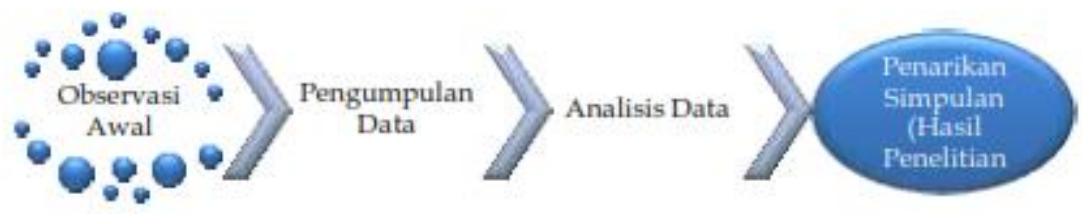

Gambar. Alur Penelitian

\section{HASIL DAN PEMBAHASAN}

\section{Perencanaan Pelaksanaan Pembelajaran Seni}

Perencanaan pembelajaran adalah pegangan guru ketika mau mengajar di dalam kelas. Perencanaan pembelajaran di Satuan PAUD adalah Rencana Pelaksanaan Pembelajaran Harian (RPPH) dan Rencana Pelaksanaan Pembelajaran Mingguan (RPPM). Berdasarkan hasil obervasi dan wawancara yang sudah dilakukan oleh peneliti, perencanaan pelaksanaan kegiatan di TK Harapan Kami, disusun berdasarkan kurikulum yang ada. Hal pertama yang dilakukan guru adalah membuat program semester. Program semester dikelompokkan sesuai dengan tema yang akan digunakan selama semester I dan semester II yang dirancang diawal tahun.

Rencana Pelaksanaan Pembelajaran Mingguan (RPPM) disusun berdasarkan program semester yang sudah dirancang sebelumnya (Aulia et al., 2022). Dari RPPM itulah guru menyusun RPPH setiap harinya. RPPH yang akan disampaikan terdiri atas pijakan lingkungan main, pijakan sebelum bermain, pijakan setelah bermain, istirahat dan kegiatan 
akhir (Nurhayani et al., 2022). Berdasarkan hasil observasi yang peneliti temukan perencanaan yang dilakukan guru tersebut sudah sesuai dengan prosedur yang ada, seperti tema yang digunakan dalam RPPH untuk proses pembelajaran saat itu adalah tema kebutuhan ku. Menurut penelitian yang dilakukan oleh Wulandari, (2020) didapat bahwa melalui kegiatan outdoor menunjukkan pengaruh yang signifikan terhadap pencapaian perkembangan kreativitas anak sebab dengan menghadirkan lingkungan belajar yang berbeda akan membantu anak menemukan variasi objek yang akan dilukiskan karena anak berhadapan langsung dan dekat dengan alam sekitar. Sedangkan oleh Manggau \& Usman, (2019) didapat hasil penelitian bahwa Melalui kegiatan tersebut disimpulkan bahwa finger painting dapat mengembangkan kreativitas anak. Karena kreativitas anak akan berkembang baik ketika bakat yang ada dalam dirinya di stimulasi dengan strategi tepat dan sesuai kebutuhan anak, salah satunya melalui pemberian kreatif yaitu finger painting.

\section{Pelaksanaan Kegiatan Pembelajaran Seni}

Pelaksanaan pembelajaran dilaksanakan sesuai dengan RPPM dan RPPH yang dirancang meliputi pembukaan, pembelajaran inti, istirahat dan penutup. Pelaksaan pembelajaran Seni di TK Harapan Kami, sudah sesuai dengan RPPH yang dirancang sebelumnya, dalam penggunaan metode guru sudah menggunakan metode bervariasi seperti metode tanya jawab, bercakap-cakap, dan pemberian tugas. Sedangkan media yang digunakan yaitu media finger painting. Kemudian kegiatan yang dilaksanakan oleh guru juga sangat menarik bagi anak sehingga anak fokus dan sangat senang dalam melaksanakan kegiatan pembelajaran Seni.

Berdasarkan hasil observasi dan wawancara yang sudah dilakukan oleh peneliti, metode pembelajaran Seni di TK Harapan Kami, menggunakan metode tanya jawab, dan pemberian tugas. Penggunaan metode pembelajaran disesuaikan dengan media dan kegiatan yang sedang dilakukan. Pada kegiatan tanggal 19 Oktober 2021, guru menggunakan metode Tanya jawab dan pemberian tugas. Metode Tanya jawab dilakukan untuk memperkenalkan kegiatan dan permainan finger painting. Selanjutnya metode pemberian tugas diberikan untuk kegiatan ketika anak memulai kegiatan finger painting

\section{Penilaian}

Penilaian terhadap anak didik dilakukan secara terencana, sistematis, dan berkesinambungan (Netriwinda et al., 2022). Di samping itu penilaian dapat memberiakan umpan balik bagi guru agar mampu menyempurnakan proses pembelajaran (Susanti et al., 2022). Dengan demikian penilaian merupakan kegiatan yang penting dalam serangkaian program di TK Mutiara Bunda. Berdasarkan hasil observasi dan wawancara yang sudah dilakukan oleh peneliti dalam pelaksanaan pengmebangan seni melalu kegiatan Finger painting di TK Harapan Kami, guru telah melakukan evaluasi pembelajaran guna mengetahui sampai mana kemampuan anak pada bidang seni. Evaluasi pembelajaran dilakukan guru dengan cara observasi langsung pada anak. Guru mengadakan evaluasi pada saat kegiatan pembelajaran berlangsung, guru memperhatikan dengan jeli mana anak yang bisa mengerjakan kegiatan sendiri. Dengan ikut sertanya guru mendampingi anak mengerjakan kegiatan, guru akan memperoleh hasil evaluasi.

Selain itu guru juga melihat perkembangan anak unjuk kerja saat kegiatan berlangsung, pada saat proses pembelajaran berlangsung guru dapat menilai anak yang bisa mengikuti kegiatan dengan baik dan mana yang tidak, sehingga guru bisa langsung membimbing anak yang masih perlu bantuan guru. Selain itu guru juga mengevaluasi setiap aspek perkembangan anak, mulai dari anak datang sampai anak pulang ke sekolah, penilaian dilakukan dengan cara observasi dengan teknik catatan anekdot dan daftar chek list (Purwasih, 2018). Dari hasil wawancara dengan ibu Dani Yuafi S.Pd sebagai guru Kelas B1 diketahui bahwa proses pembelajaran Seni anak di TK Harapan Kami termasuk dalam kategori baik. Karena dari perencanaan pembelajaran yang dirancang sesuai acuan yang ada 
dan diterapkan pada pelaksaanaan pembelajaran dengan didukung media Finger painting dan kemampuan guru dalam mengajar. Selain itu dalam proses mengajar guru juga menilai kemampuan anak untuk dijadikan evaluasi guru dan tindak lanjut pada proses pembelajaran berikutnya.

Untuk diketahui hasil pembelajaran Seni anak di TK Harapan Kami sangat cocok menggunakan media Finger painting karena media tersebut merupakan media yang menarik dan tidak membosankanya jika digunakan. Senada dengan pendapat Dewi, (2017) menyatakan Media adalah segala sesuatu yang dapat digunakan untuk menyalurkan pesan yang dapat merangsang pikiran, perasaan, perhatian, dan kemauan siswa untuk belajar. Dapat dipahami bahwa media Finger painting adalah alat bantu proses belajar mengajar yang dapat dipergunakan untuk merangsang pikiran, perasaan, perhatian dan kemampuan atau ketrampilan pelajar sehingga dapat mendorong terjadinya proses belajar pada peserta didik.

\section{SIMPULAN}

Finger painting bermanfaat dalam mengembangkan kreativitas pribadi anak yang mandiri, penuh imajinasi dan mengasah bakat dalam pembelajaran Seni. Finger painting sebagai kegiatan yang menarik dan menyenangkan sebagai pendorong pada anak dalam bentuk semangat, rasa antusias dan keaktifan anak, Finger painting juga dapat melatih proses pengembangan kreativitas anak, meliputi kelancaran, keaslian/alami, dan keluwesan.

\section{UCAPAN TERIMA KASIH}

Peneliti mengucapkan terimakasih banyak kepada Kepala Sekolah dan Guru TK Harapan Kami atas kerjasama yang baik selama penelitian ini dilakukan. Peneliti juga ucapkan terimakasih kepada editor dan reviwer jurnal yang telah memperbaiki artikel ini menjadi lebih baik.

\section{DAFTAR PUSTAKA}

Anggraini, S., Jaya, T. B. S., \& Sofia, A. (2018). Pengaruh Aktivitas Permainan Finger Painting terhadap Pengenalan Warna Anak Usia 5-6 Tahun. Jurnal Pendidikan Anak, 4(2).

Aulia, R., Yaswinda, Y., \& Movitaria, M. A. (2022). Penerapan Model Evaluasi Cipp dalam Mengevaluasi Penyelenggaraan Lembaga PAUD Tentang Pendidikan Holistik Integratif di Nagari Taram. Jurnal Inovasi Penelitian, 2(8), 2363-2372.

Creswell, J. W. (2015). Research Design: Qualitative, Quantitative, and. Mixed Methods Approaches. Sage Publications.

Dewi, K. (2017). Pentingnya Media Pembelajaran untuk Anak Usia Dini. Raudhatul Athfal, 1. https://doi.org/10.19109/ra.v1i2.2676

Fakhriyani, D. V. (2016). Pengembangan kreativitas anak usia dini. Wacana Didaktika, 4(2), 193-200. https://doi.org/10.31102/wacanadidaktika.4.2.193-200

Fauziah, N. (2013). Penggunaan Media Bahan Alam Untuk Meningkatkan Kreativitas Anak. Jurnal Ilmiah Visi, 8(1), 23-30. https:// doi.org/10.21009/JIV.0801.4

Harahap, F. (2019). Kemampuan Motorik Halus Anak melalui Kegiatan Melipat Kertas Origami. Atṭāluna: Journal of Islamic Early Childhood Education, 2(2), 57-62. https://doi.org/10.32505/atfaluna.v2i2.1284

Herlina. (2013). Perkembangan Masa Remaja(Usia 11/12 - 18 tahun). Mengatasi Masalah Anak Dan Remaja. https:// doi.org/10.1016/j.jvoice.2013.08.014

Hulukati, W., \& Hulukati, W. (2015). Peran lingkungan keluarga terhadap perkembangan anak. Jurnal Musawa IAIN Palu, 7(2), 265-282.

Kristin, F. (2016). Analisis model pembelajaran discovery learning dalam meningkatkan hasil belajar siswa SD. Jurnal Pendidikan Dasar PerKhasa, 2(1), 90-98. http:/jurnal.stkippersada.ac.id/jurnal/index.php/JPDP/article/view/25 
DOI: $10.31004 /$ obsesi.v6i4.1978

Kurniati, E., \& Rachmawati, Y. (2010). Strategi Pengembangan Kreativitas pada Anak Usia Taman Kanak-Kanak. Kencana, Jakarta.

Maghfuroh, L., \& Putri, K. C. (2017). Pengaruh finger painting terhadap perkembangan motorik halus anak usia prasekolah di tk sartika i sumurgenuk kecamatan babat lamongan. Journal of Health Sciences, 10(1). https:// doi.org/10.33086/jhs.v10i1.144

Manggau, A., \& Usman, A. (2019). Kreativitas anak melalui melukis dengan jari (Finger Painting) di Taman Kanak-Kanak Kota Makassar.

Munandar, U. (2021). Pengembangan kreativitas anak berbakat. PT Rineka Cipta.

Nasution, N., \& Yaswinda, I. M. (2020). Jurnal Obsesi: Jurnal Pendidikan Anak Usia Dini. Jurnal Obsesi: Jurnal Pendidikan Anak Usia Dini, 4(1), 230-236. https://doi.org/10.31004/obsesi.v4i1.311

Netriwinda, N., Yaswinda, Y., \& Movitaria, M. A. (2022). Evaluasi Program Pendidikan Paud Holistik Integratif dengan Model Cipp Di Nagari Pandam Gadang Kecamatan Gunuang Omeh. Jurnal Inovasi Penelitian, 2(8), 2343-2352.

Nurhayani, N., Yaswinda, Y., \& Movitaria, M. A. (2022). Model Evaluasi Cipp Dalam Mengevaluasi Program Pendidikan Karakter Sebagai Fungsi Pendidikan. Jurnal Inovasi Penelitian, 2(8), 2353-2362.

Nursyam, R., Setiawati, R., \& Haerudin, D. (2020). Ekspresi diri berbasis gerak maknawi melalui penciptaan karya tari Lenggang Meniti Asa. Senakreasi: Seminar Nasional Kreativitas Dan Studi Seni, 2, 79-97.

Pamadhi, H. (2008). Ruang Lingkup Seni Rupa Anak. Universitas Terbuka. Jakarta.

Pebriana, P. H. (2017). Analisis penggunaan gadget terhadap kemampuan interaksi sosial pada anak usia dini. Jurnal Obsesi: Jurnal Pendidikan Anak Usia Dini, 1(1), 1-11. https://doi.org/10.31004/obsesi.v1i1.26

Purwasih, W. (2018). Teknik Penilaian Unjuk Kerja dan Catatan Anekdot Sebagai Upaya Pemantauan Perkembangan Anak di PAUD Aisyiyah Cabang Kartasura Sukoharjo Jawa Tengah. Jurnal Warna, 2(2).

Ramdini, T. P., \& Mayar, F. (2019). Peranan Kegiatan Finger Painting terhadap Perkembangan Seni Rupa dan Kreativitas Anak Usia Dini. Jurnal Pendidikan Tambusai, 3(3), 14111418.

Sugiyono. (2015). Metode Penelitian Pendidikan Pendekatan Kuantitatif, Kualitatif, dan R \& D. Alfabeta.

Susanti, D., Yaswinda, Y., \& Movitaria, M. A. (2022). Program Holistik Intgratif Model Cipp di TK Se Kecamatan Lareh Sago Halaban. Jurnal Inovasi Penelitian, 2(8), 2631-2638.

Suwarini. (2014). Mengembangkan Kreatifitas Anak Melalui Kegiatan Finger Painting Pada Anak Kelompok B Di Tk Pertiwi Karangtengah, Kecamatan Sragen Kabupaten Sragen Tahun Ajaran 2013/2014. Universitas Muhammadiyah Surakarta.

Umroh, I. L. (2019). Peran Orang Tua Dalam Mendidik Anak Sejak Dini Secara Islami Di Era Milenial 4.0. Ta'lim: Jurnal Studi Pendidikan Islam, 2(2), 208-225.

Wulandari, A. (2020). Meningkatkan Kreativitas Anak melalui Teknik Finger Painting di KB Al Jannati Gampong Jawa Kota Banda Aceh. Jurnal Ilmiah Mahasiswa Pendidikan Anak Usia Dini, 5(1). 